\title{
IDENTIFICATION OF DRUG-RELATED PROBLEMS IN PATIENTS WITH UPPER ACUTE RESPIRATORY TRACT INFECTIONS IN TEBET SUBDISTRICT HEALTH CENTER
}

\author{
ATIKA WAHYU PUSPITASARI ${ }^{1 *}$, OLYVA CESSARI LARAS SERUNI ${ }^{1}$, LINA NADHILAH ${ }^{2}$ \\ ${ }^{1}$ Clinical Pharmacy Laboratory, Faculty of Pharmacy, Universitas Indonesia, Depok, Jawa Barat 16424, Indonesia. ${ }^{2}$ Tebet Subdistrict Health \\ Center, Jakarta 12820, Indonesia. Email: atikawp.mi@gmail.com \\ Received: 26 September 2019, Revised and Accepted: 17 December 2019
}

\section{ABSTRACT}

Objective: Acute respiratory tract infection (ARTI) is common and has the highest death rate in children, especially in growing countries such as Indonesia. The aim of the research is to identify drug-related problems (DRPs) in pediatric ARTI patients based on the DRP classification by Cipolle, Strand, and Morley, which included categories such as unnecessary drug therapy, need additional therapy, ineffective drug, dosage adjustments such as too low or too high, and adverse drug reaction which is drug interaction.

Methods: The design of the study was cross-sectional and descriptive with a retrospective method. The sample of the study was the overall prescriptions to upper respiratory tract infection patients in Tebet Subdistrict Health Center from July to December 2018 that fulfilled all of the inclusion criteria, using the total sampling method. Total samples that were analyzed were from 179 sheets of prescription with a total of 498 prescriptions.

Results: The results of the research based on each parameter were inaccurate drug selection (9.5\%), inaccurate indication (12.8\%), mismatched dose (79.9\%), and drug interaction (0.6\%).

Conclusion: DRPs in ARTI pediatric patients resulted in a high-risk condition so that the health facilities need to improve their prescribing pattern and monitor and manage each therapy as well as do a routine prescription assessment to minimize the incidence of DRPs and achieve a rational drug usage.

Keywords: Acute respiratory tract infection, Drug-related problems, pediatric, Tebet subdistrict health center, Cipolle.

(c) 2020 The Authors. Published by Innovare Academic Sciences Pvt Ltd. This is an open access article under the CC BY license (http://creativecommons. org/licenses/by/4. 0/) DOI: http://dx.doi.org/10.22159/ijap.2020.v12s1.FF009

\section{INTRODUCTION}

Acute respiratory tract infection (ARTI) is one of many diseases caused by viruses or bacteria. ARTI has a high mortality potential, especially in children [1]. This was shown by statistical data published by the World Health Organization in 2018 that stated that the world's most frequent cause of mortality for children $<5$ years old was ARTI. A survey conducted by the United Nations Children's Fund in 2016 showed that the mortality rate for ARTI in children $<5$ years old had increased from $15 \%$ in 2015 to $16 \%$ in 2016 [2]. In addition, the prevalence of ARTI in developing countries, such as Bangladesh, India, Indonesia, and Nepal, accounts for $40 \%$ of the global mortality rate due to ARTI in various age groups [3]. Data from the Ministry of Health in 2015 showed that ARTI ranked first of the 10 most prevalent diseases in Indonesia, with a total of 50,555 cases $(39.85 \%)$

The high prevalence of ARTI in pediatric patients results in drug prescription and usage [4]. Pediatric patients are at high risk of medication error due to pharmacokinetic mechanisms and their organs' imperfect physiologic function [5]. Special attention needs to be taken when providing drug therapy to pediatric patients to avoid treatment problems and so that adverse effects or treatment failure can be minimized. One effort to prevent this is by analyzing drug-related problems (DRPs) in prescribed drugs [6].

A DRP is an unexpected event in a patient's experience that is a result of or suspected to be a result of drug therapy, thereby affecting the expected success of healing. A DRP can be in the form of an incorrect dose that is either too high or too low, an unsuitable indication for the drug therapy, patient compliance, drug selection errors, and adverse reactions $[7,8]$. DRPs put the patient's quality of life at high risk, increase patient morbidity and mortality, and increase the cost of treatment. This study used classification according to Cipolle, Strand, and Morley conducting the DRP analysis since that system tends to prioritize safety and successful drug therapy for patients [9].

\section{METHODS}

This research is a descriptive retrospective study. This study used a cross-sectional study design and used secondary data on drug prescription in pediatric ARTI patients in the Tebet Subdistrict Health Center for the period from July 2018 to December 2018. This research was conducted at the Tebet Subdistrict Health Center, South Jakarta, for 6 months from February 2019 to July 2019. Data retrieval was conducted over 2 months from February 2019 to March 2019. The study has received a research permit from Unit Pelaksana Pelayanan Terpadu Satu Pintu, Kota Administrasi Jakarta Selatan by number 237/082.61.

The study population was all patient prescriptions in the IMDT clinic of Tebet Subdistrict Health Center in the period from July 2018 to December 2018. Samples for this study were all prescriptions in the IMDT Clinic, Subdistrict Health Center during the period from July to December 2018 that met the inclusion criteria. Sampling was done by the total sampling method. The inclusion criteria of this study included prescriptions for pediatric ARTI patients with an ICD X code for upper ARTI, consisting of otitis media (H66), sinusitis (J01), pharyngitis (J02), tonsillitis (J03), and laryngitis-tracheitis (J04); prescriptions given to patients aged $<6$ years; and prescriptions that only had one ICD X diagnosis code. In addition, the exclusion criteria for this study were prescriptions that were incomplete and prescriptions that were not entered into the system so that they were unread.

In this study, DRP classification based on Cipolle et al. (2012) was recategorized into four major parameters, which were the accuracy of drug selection (consisting of unnecessary drug therapy and adjunctive drug therapy), accuracy of indication (ineffective drugs), dosage suitability 
(excessive or insufficient dose), and the potential for drug interactions [7]. In addition, patient characteristics consisting of the patient's age, sex, and body weight as well as the patient's prescribing picture, both drug classes and drug preparations became the sample overview in this study.

Data analysis was performed in 2018 by univariate analysis using Microsoft Excel macOS. This analysis looked at the frequency distribution of DRPs in pediatric ARTI patients based on several parameters. Furthermore, the data were used to analyze the percentage of DRPs and the possible occurrence of interactions due to drug therapy using the IBM Micromedex® Web Access Application and/or Drug Interaction Checker Medscape application

\section{RESULTS}

The number of prescriptions used as research samples was 179 prescription pages. The samples were secondary data (electronic prescription or e-prescription) that were obtained from the database of Tebet Subdistrict Health Center's information system in the SIKDA Optima online site. These are the characteristics of the research samples that were categorized based on the patients' sex, age, and weight.

Based on Table 1, more pediatric ARTI patients were male (55.3\%) than female (44.7\%). ARTI cases most commonly happened in the age group of 3-6 years old (81.6\%). Patients with normal body weight of 10-18 kg (78.2\%) also experienced the highest incidence of ARTI compared to both the underweight and the overweight categories.

There were a total of 179 prescription sheets consisting of 498 drug prescriptions. Drug prescription in ARTI patients could be categorized into two groups, according to the active substances (drug classes) of each drug prescription and the drug preparation. The following are an overview of drug prescriptions:

Based on Table 2, the drug prescription-based category was further categorized into several categories: The most used drug in the category of analgesic-antipyretic was paracetamol $(19.4 \%)$, the most used corticosteroid was dexamethasone (14.3\%), most used supplement was Vitamin C (12.0\%), most used antihistamine was CTM (11.8\%), most used antibiotic was amoxicillin (9.6\%), most used cough remedy was expectorant (8.1\%), most used bronchodilator was salbutamol $(2.3 \%)$, and the most used drug within the other category was antiemetic $(0.6 \%)$.

Based on Table 3, the drug preparations prescribed in pediatric ARTI patients consisted of syrup (50.6\%), powder (24.7\%), dry syrup (13.5\%), tablets $(10.0 \%)$, suspension $(0.6 \%)$, drops $(0.4 \%)$, and cream $(0.2 \%)$.

In this study, an event could be classified as a DRP if in one sheet of a pediatric ARTI patient's prescription, there were one or more discrepancies in one or more parameters of the four categories. The percentage of DRP events in each category can be seen in the following table:

From Table 4, it can be concluded that the percentage of incorrect drug therapy is $9.5 \%$, with $8.9 \%$ needing adjunctive drug therapy and $0.6 \%$ unnecessary drug therapy.

Table 1: Characteristics of research samples based on the number of patients

\begin{tabular}{lll}
\hline Sample characteristics & Frequency $(\mathbf{n = 1 7 9})$ & Percentage \\
\hline Sex & & \\
$\quad$ Female & 80 & 44.7 \\
$\quad$ Male & 99 & 55.3 \\
Age group (years) & & \\
$\quad 0-<3$ & 33 & 18.4 \\
$3-<6$ & 146 & 81.6 \\
Patients' weight (kg) & & \\
$\quad<10$ & 5 & 2.8 \\
$10-18$ & 140 & 78.2 \\
$>18$ & 34 & 19.0 \\
\hline
\end{tabular}

Based on Table 5, inaccurate indication happened in 23 patient prescriptions, consisting of incorrect drug prescription and ineffective drug for the patient.

It is shown in Table 6 that the percentage of dose unsuitability was $79.9 \%$, including inadequate $(27.9 \%)$ and excessive $(52.0 \%)$ dose

Based on Table 7, the potential incidence of drug interactions in pediatric ARTI prescriptions is $0.6 \%$, namely, one case of the interaction between erythromycin and dexamethasone.

\section{DISCUSSION}

Characteristics of the research samples

The characteristics of the research samples consisted of gender, patient age, and patient weight. There were a higher percentage of male patients (55.3\%) than female ones (44.7\%) in the ARTI patients. This was due to greater outdoor activities and air exposure in male toddlers, hence a lower immune system [10].

The incidence of ARTI was higher in preschool children (3-<6 years) at $81.6 \%$ since toddlers have begun to actively engage in outdoor activities,

Table 2: Overview of drug prescriptions in pediatric ARTI patients based on drug category

\begin{tabular}{|c|c|c|}
\hline Drug categories & $\begin{array}{l}\text { Number } \\
(n=789)\end{array}$ & Percentage \\
\hline \multicolumn{3}{|l|}{ Analgesic-antipyretic } \\
\hline Paracetamol & 153 & 19.4 \\
\hline \multicolumn{3}{|l|}{ Corticosteroid } \\
\hline Dexamethasone & 113 & 14.3 \\
\hline \multicolumn{3}{|l|}{ Supplement } \\
\hline Vitamin C & 95 & 12.0 \\
\hline Vitamin B complex & 47 & 6.0 \\
\hline Suprabion & 22 & 2.8 \\
\hline Vitamin B6 & 3 & 0.4 \\
\hline \multicolumn{3}{|l|}{ Antihistamine } \\
\hline Chlorpheniramine maleate (CTM) & 93 & 11.8 \\
\hline Cetirizine & 41 & 5.2 \\
\hline \multicolumn{3}{|l|}{ Antibiotic } \\
\hline Amoxicillin & 76 & 9.6 \\
\hline Erythromycin & 1 & 0.1 \\
\hline Cotrimoxazole & 1 & 0.1 \\
\hline \multicolumn{3}{|l|}{ Cough remedy } \\
\hline Expectorant & 64 & 8.1 \\
\hline Mucolytic & 48 & 6.1 \\
\hline \multicolumn{3}{|l|}{ Bronchodilator } \\
\hline Salbutamol & 18 & 2.3 \\
\hline \multicolumn{3}{|l|}{ Others } \\
\hline Antiemetic: domperidone & 6 & 0.7 \\
\hline Antacid & 6 & 0.7 \\
\hline Acyclovir tablets & 1 & 0.1 \\
\hline Nystatin drop & 1 & 0.1 \\
\hline Chloramphenicol drop & 1 & 0.1 \\
\hline Acyclovir cream & 1 & 0.1 \\
\hline
\end{tabular}

ARTI: Acute respiratory tract infection

Table 3: Prescribed drug preparation for pediatric ARTI patients based on the number of prescriptions

\begin{tabular}{lll}
\hline Drug preparations & Number $(\mathbf{n = 4 9 8 )}$ & Percentage \\
\hline Syrup & 252 & 50.6 \\
Powder & 123 & 24.7 \\
Dry syrup & 67 & 13.5 \\
Tablet & 50 & 10.0 \\
Suspension & 3 & 0.6 \\
Drop & 2 & 0.4 \\
Cream & 1 & 0.2 \\
\hline
\end{tabular}


Table 4: Percentage of accuracy of drug selection

\begin{tabular}{llllll}
\hline Accuracy of drug selection & \multicolumn{2}{l}{ Amount of patients' prescriptions } & & & Total of R/s \\
\cline { 2 - 3 } & Number $(\mathbf{n = 1 7 9 )}$ & Percentage & & Number (n=498) & Percentage \\
\hline Accurate drug selection & 162 & 90.5 & & 480 & 96.4 \\
$\begin{array}{l}\text { Inaccurate drug selection } \\
\quad \text { Needing adjunctive drug therapy }\end{array}$ & 16 & 8.9 & & 16 & 3.2 \\
$\quad$ Unnecessary drug therapy & 1 & 0.6 & 2 & 0.4 \\
\hline
\end{tabular}

Table 5: Percentage of accurate indications

\begin{tabular}{llllll}
\hline $\begin{array}{l}\text { Accuracy of } \\
\text { indication }\end{array}$ & \multicolumn{2}{l}{$\begin{array}{l}\text { Number of patient } \\
\text { prescriptions }\end{array}$} & & & \multicolumn{2}{l}{ Total of R/s } \\
\cline { 2 - 3 } \cline { 5 - 6 } \cline { 5 - 6 } & $\begin{array}{l}\text { Number } \\
(\mathbf{n = 1 7 9 )}\end{array}$ & Percentage & & $\begin{array}{l}\text { Amount } \\
(\mathbf{n = 4 9 8 )}\end{array}$ & Percentage \\
\hline $\begin{array}{l}\text { Accurate } \\
\text { indication }\end{array}$ & 156 & 87.2 & & 473 & 95.0 \\
$\begin{array}{l}\text { Inaccurate } \\
\text { indication }\end{array}$ & 23 & 12.8 & & 25 & 5.0 \\
\hline
\end{tabular}

Table 6: Percentage of dosage suitability

\begin{tabular}{llllll}
\hline $\begin{array}{l}\text { Dosage } \\
\text { suitability }\end{array}$ & \multicolumn{2}{l}{$\begin{array}{l}\text { Number of patients' } \\
\text { prescriptions }\end{array}$} & & \multicolumn{2}{l}{ Total of R/s } \\
\cline { 2 - 3 } \cline { 5 - 6 } & $\begin{array}{l}\text { Number } \\
(\mathbf{n = 1 7 9 )}\end{array}$ & Percentage & $\begin{array}{l}\text { Number } \\
\text { (n=498) }\end{array}$ & Percentage \\
\hline $\begin{array}{l}\text { Suitable dose } \\
\text { Unsuitable dose }\end{array}$ & 36 & 20.1 & & & \\
$\begin{array}{l}\text { Inadequate dose } \\
\text { Excessive dose }\end{array}$ & 50 & 27.9 & & 54 & 60.6 \\
\hline
\end{tabular}

Table 7: Percentage of potential drug interactions

\begin{tabular}{llllll}
\hline $\begin{array}{l}\text { Potential drug } \\
\text { interaction }\end{array}$ & \multicolumn{2}{l}{$\begin{array}{l}\text { Number of patients' } \\
\text { prescriptions }\end{array}$} & & \multicolumn{2}{l}{ Total of R/s } \\
\cline { 2 - 3 } \cline { 5 - 6 } & $\begin{array}{l}\text { Number } \\
(\mathbf{n = 1 7 9 )}\end{array}$ & Percentage & & $\begin{array}{l}\text { Number } \\
(\mathbf{n = 4 9 8})\end{array}$ & Percentage \\
\hline $\begin{array}{l}\text { No occurrence of } \\
\text { drug interaction }\end{array}$ & 178 & 99.4 & & 497 & 99.8 \\
$\begin{array}{l}\text { Occurrence of } \\
\text { drug interaction }\end{array}$ & 1 & 0.6 & & \\
$\begin{array}{l}\text { Erythromycin- } \\
\text { Dexamethasone }\end{array}$ & & & & & \\
\hline
\end{tabular}

such as playing, socializing, finding out about science, and being exposed to air on the highway, and some have even started education in formal schools and bought food carelessly, thereby increasing vulnerability to certain diseases, especially infectious diseases $[10,11]$. Within this age group, children also experienced their first infection when they had not formed optimal immunity, hence the higher incidence of ARTI [12].

Patient's weight was also a sample characteristic in this study, with the highest number being $10-18 \mathrm{~kg}(78.2 \%)$. This is because the toddlers' weight, which is associated with age, will affect the toddler's nutritional status. The better the nutritional status of the toddler, the incidence of disease tends to decrease. If their nutritional status tends to be good, then there are other factors that might affect their health, such as pollution exposure, the environment, socioeconomic status, and other factors [13].

\section{Overview of prescriptions for pediatric ARTI patients}

ARTI and its accompanying symptoms will affect drug prescribing, which consists of antibiotics, antihistamines, analgesics, expectorants, and multivitamins. Analgesic-antipyretic drugs were the most commonly prescribed drugs for pediatric ARTI patients. This was shown by the usage of paracetamol, which reached the percentage of $19.3 \%$. Paracetamol is generally prescribed to relieve pain and/or fever in pediatric ARTI patients [14].

Corticosteroid drugs in the form of dexamethasone with the percentage of $14.3 \%$ were the second most-prescribed drug for pediatric ARTI patients. Anti-inflammatory drugs classified as corticosteroids aim to suppress the inflammatory response and immune response by inhibiting the formation of bradykinin and the release of neuropeptides from nerve endings that can cause pain since ARTI patients usually have pain complaints, especially in the throat or ears, that are caused by inflammation [15]. The administration of anti-inflammatory drugs is expected to relieve pain complaints in pediatric ARTI patients. However, the use of corticosteroids in pediatric patients is more limited since they inhibit the growth of children through somatostatin stimulation and eventually inhibit growth hormone [14].

The highest percentage of vitamin use was Vitamin C, which was equal to $12.0 \%$ of all drugs. This is because Vitamin $\mathrm{C}$ is an essential vitamin for humans and a cofactor for various metabolic reactions that can enhance the immune system. The use of Vitamin C along with ironcontaining supplements will increase absorption in the gastrointestinal tract, thereby improving the quality and nutritional status in pediatric patients [16].

The fourth most-prescribed drug for pediatric ARTI patients is antihistamines. Antihistamines are used as a therapy for certain allergies and can also be used in combination with cough medicines due to its sedative effect, hence its ability to suppress the itching in the throat [17].

Oral antibiotics are widely used for the treatment of ARTI, especially in pediatric patients. Antibiotics occupied the fifth place in the mostprescribed drugs for pediatric ARTI patients, with a total use of amoxicillin as high as $9.6 \%$. The use of antibiotics is aimed to prevent and overcome bacteria that cause infections in ARTI patients [14]. The use of amoxicillin therapy is recommended for recurrent ARTI to avoid resistance to cotrimoxazole [18].

Cough medicine was given to pediatric ARTI patients to reduce symptoms in the form of phlegm cough, both expectorant (8.1\%) and mucolytic (6.1\%). In addition, bronchodilators such as salbutamol were given to $2.3 \%$ to relieve symptoms related to shortness of breath and asthma, due to the exposure to infectious agents on the airways [19]. Antiemetics are prescribed to relieve nausea and vomiting in pediatric ARTI patients [20]. Antacids are used to treat gastritis to neutralize excessive stomach acid. Antacids contain weak bases of aluminum hydroxide or magnesium hydroxide [21]. Antivirals in the treatment of pediatric ARTI patients are intended for ARTI caused by viruses, such as influenza viruses [22].

In addition to oral drug prescriptions, pediatric ARTI patients were also given topical medications. The administration of topical drugs is aimed at local effects. Topical medications consisted of acyclovir cream, chloramphenicol drops, and also nystatin drops. Chloramphenicol drops and nystatin drops are used as antiseptics in certain parts of the infected organ, such as the ears and mouth [1]. As for the administration of acyclovir cream, it is possible that the patients experienced other diseases such as herpes simplex or varicella so that topical therapy was given [23]. 
In addition to the description based on the drug categories, drug prescriptions were also classified based on their preparations. The most-prescribed drug preparation was syrup preparation. The provision of syrup is related to the non-optimal ability of pediatric patients to swallow. Thus, they require drugs that are easily swallowed. Syrup also has a sweet taste and additional flavors and aromas so that pediatric patients are interested $[18,24]$. Powder was also prescribed often for pediatric ARTI patients. This is due to the required dose adjustment for pediatric ARTI patients [25]. Another reason is the limited drug stock in the pharmacy of the public health center. Pediatric patients also do not yet have the optimal ability to swallow (administration route) and maintain compliance in consuming many drugs [24].

\section{Identification of DRPs}

\section{Accuracy of drug selection}

Adjunctive drug therapy is carried out if the patient is diagnosed with an illness according to the ICD X code but does not get the appropriate drug therapy. Additional drug therapy is common in the diagnosis of J03 (tonsillitis). This happens because many prescribed drugs are given to only reduce the symptoms of the disease without giving other drugs aimed at treating the infection, for example, giving paracetamol (analgesic-antipyretic) and ambroxol (cough medicine) alone without being accompanied by antibiotics or an anti-inflammatory.

Unnecessary drug therapy occurred in one prescription that had the ICD X diagnosis code of J03 (tonsillitis). The administration of acyclovir in the form of tablets and cream was considered unnecessary. Antiviral prescription in pediatric ARTI patients is considered unnecessary because acyclovir is generally prescribed for herpes patients or varicella infections to reduce the length of fever and the number of lesions in the body due to viruses [23].

Unnecessary drug therapy may also occur in some drug prescriptions because the drugs decrease the symptoms of the disease or improve the patient's condition. Thus, overuse of some drugs such as domperidone, antacids, and supplements containing iron, such as Suprabion ${ }^{\circledR}$ often occur. Prescription of domperidone in pediatric ARTI patients aims to treat nausea and vomiting due to fever suffered by the patients. In addition, pediatric ARTI patients are given antacids to treat stomach pain due to increased stomach acid [26]. Supplementation is also done to maintain the child's appetite and nutritional status during infection. However, high doses of these supplements will actually affect the growth of these pediatric patients. Thus, it should be used according to the patient's condition [16].

\section{Accuracy of indication}

Inaccurate indication often happened with prescription of Suprabion ${ }^{\circledR}$ multivitamin. Suprabion multivitamin use is intended for undernourished patients. The supplement, however, was also prescribed for children with normal nutritional status according to their body weight and age. This prescription can potentially cause DRP since prescribing Suprabion multivitamin in normal and overnourished patients is ineffective and irrational. However, this was not supported by information about laboratory results that might be a parameter for supplementation. On the other hand, iron supplementation for pediatric patients tends to increase the absorption of Vitamin $\mathrm{C}$ in the gastrointestinal tract, which can improve the nutritional status of pediatric patients. Management that needs to be done and is a concern is the prescription of drugs in accordance with general guidelines for pediatric patients and the appropriate use of vitamins and supplements to achieve judicious use of drugs [16].

\section{Dose suitability}

Dose unsuitability consists of inadequate and excessive doses. Based on this research, inadequate dose mostly happened in administration of syrup preparation, especially in the prescription of amoxicillin and paracetamol. An antibiotic has to be prescribed for 7 days, unsuitable or inadequate dose may increase the prevalence of antibiotic resistance $[27,28]$. Meanwhile, there is no explanation for the inadequate dose of paracetamol. It is an over-the-counter drug so it is safer if given according to the appropriate dose. However, an overdose will cause hepatotoxicity [29].

Excessive dose is a higher than standard administration of drug doses [30]. In this case, excessive dose means that it exceeds the minimum toxic level, so the potential for toxic effects will be higher. In this study, the incidence of overdose occurred in dexamethasone drugs and supplements. The broad use of dexamethasone, its convenience to obtain, and its quick therapeutic effect cause this drug to get a lot of abuse, for example, in the form of incompatibility with indications or doses. Dexamethasone in high doses will cause damage to vital body, such as the liver, kidneys, and gastric mucosa. Damage to these organs causes decreased function and cell death (cell necrosis), thus affecting the body health in general [31].

\section{Potential drug interaction}

Potential drug interaction events also occurred in the dexamethasoneerythromycin prescription. Dexamethasone belongs to the corticosteroid group that can reduce the expression of inflammatory genes through the inhibition of NF-kB induced by histone acetylation, whereas erythromycin is a macrolide antibiotic that is effective for diseases related to chronic breathing [32]. Interactions that occur include inhibition of erythromycin metabolism by dexamethasone. This occurs by the effect of dexamethasone on the intestinal enzymes in CYP3A4 metabolism. In addition, the combination of erythromycin-dexamethasone can increase the effects of the corticosteroid by reducing the inflammatory effect shown by inhibition of the PI3K-delta/Akt pathway. This interaction also causes an increase in expression of alpha GR receptors [32]. Since the interactions are quite serious, it is necessary to replace erythromycin or use an alternative medicine. Drug replacement is done by replacing the antibiotic with commonly given antibiotics such as amoxicillin or eliminating the use of anti-inflammatory drugs in patients during erythromycin use. In addition, health facilities should also file or collect data on interactions that occur as well as routine monitoring of all types of interactions $[1,33]$.

\section{CONCLUSION}

DRPs in ARTI pediatric patients resulted in high-risk conditions; therefore, the health facilities need to improve their prescribing patterns and monitor and manage each therapy, and perform routine prescription assessment to minimize the incidence of DRPs and achieve rational drug usage.

\section{ACKNOWLEDGMENTS}

The authors would like to thank Tebet Subdistrict Health Center for providing permission and data for this study.

\section{CONFLICTS OF INTEREST}

The authors declare that they have no conflicts of interest.

\section{REFERENCES}

1. Ministry of Health. Decree of the Minister of Health of the Republic of Indonesia No. HK 02.02/MENKES/514/2015 about Clinical Practice Guidelines for Doctors in First-level Health Care Facilities. Jakarta: Ministry of Health; 2015.

2. World Health Organization. World Health Statistics 2018: Monitoring Health for the SDGs. Switzerland: World Health Organization; 2018.

3. World Health Organization. WHO Model Formulary for Children. Jenewa, Switzerland: World Health Organization; 2010.

4. Ministry of Health. Integrated Management Chart for Sick Children. Jakarta: Ministry of Health; 2015.

5. Dipiro J, Talbert R, Yee G, Matzke G, Welss B, Posey M. Pharmacotherapy: A pathophysiologic approach. Amerika Serikat: McGraw Hill Companies; 2017. p. 10.

6. Department of Health of the Republic Indonesia. Guidelines for Pharmaceutical Services for Pediatric Patients. Jakarta: Ditjen Bina Kefarmasian dan Alat Kesehatan Departemen Kesehatan Republik Indonesia; 2009 
7. Cipolle RJ, Strand LM, Morley PC. Pharmaceutical Care Practice: The Patient-centered Approach to Medication Management Services. $3^{\text {rd }}$ ed. Minnesota, Amerika Serikat: McGraw-Hill Education; 2012. p. 3.

8. Suryani D, Bahtiar A, Andrajati R. Pharmacist involvement to decrease drug-related problems among geriatric patients in Indonesian primary health centers. Asian J Pharm Clin Res 2017;10:102-7.

9. Björkman IK, Sanner MA, Bernsten CB. Comparing 4 classification systems for drug-related problems: Processes and functions. Res Social Adm Pharm 2008;4:320-31.

10. Sari NI, Ardianti A. Relationship between Age and sex to the Incidence of Acute Respiratory Infections of Toddler at Tembilahan Hulu Public Health Center. Nigeria: An-Nadaa; 2017. p. 26-30.

11. Maharani D, Yani FF, Lestari Y. Profile of toddlers with acute upper respiratory tract infections in pediatric clinics at RSUP Dr. M. Djamil Padang in 2012-2013. J Kesehatan Andalas 2017;6:152-7.

12. Misnadiarly M. Various Diseases in Children. Jakarta: EGC; 2008.

13. Febrianto W, Mahfoedz I, Mulyanti M. Nutritional status is related to the incidence of ARI in infants at Wonosari I Gunungkidul in 2014. J Gizi Dietetik Indones 2015;2:113-8

14. Mar'atus SN, Susanti R, Untari EK. Overview of treatment and direct medical costs of pediatric ARI patients. J Manajemen Pelayanan Farm 2017;7:40-8

15. Erlangga ME, Sitanggang RH, Bisri T. Comparison of the administration of dexamethasone $10 \mathrm{mg}$ with $15 \mathrm{mg}$ intravenously as an analgesic adjuvant to the scale of postoperative pain in patients undergoing modified radical mastectomy. J Anestesi Perioratif 2015;3:146-154.

16. Lintang AM. Adequacy of Fe and Vitamin C Intake in Malnourished Children under Five in Joho Village, Mojolaban District, Sukoharjo Regency, Dissertation. Surakarta: Faculty of Public Health Universitas Muhammadiyah; 2017

17. Linnisa UH, Wati SE. The rationality of prescribing expectorant and antitussive cough medicines in the teak medika pharmacy. Indones $\mathrm{J}$ Med Sci 2014;1:30-9.

18. Wahyono D, Hapsari I, Astuti IW. The pattern of treatment of acute respiratory tract infections under five years old children (toddlers) outpatient at Purwareja Klampok Banjarnegara Regency public health center in 2004. Majalah Farm Indones 2008;19:20-4.

19. Gern JE. Viral respiratory infection and the link to asthma. Pediatr Infect Dis J 2008;27:S97-103.

20. Cotton M, Innes S, Jaspan H, Madide A, Rabie H. Management of upper respiratory tract infection in children. S Afr Farm Pract 2004;50:6-12.

21. Hamid R, Noorrizka G, Wijaya IN, Yuda A. Profile of the use of antacid drugs obtained by self-medication. J Farm Komunitas 2014;1:49-52

22. Fujiastuti G. Evaluation of Drug Related Problems (DRPs) of Acute Respiratory in Fections (ARI) in Pediatric Patients in Inpatient Installations, Dissertation. Jakarta: Fakultas Kedokteran dan Ilmu Kesehatan UIN Syarif Hidayatullah; 2017.

23. Theresia M, Hadinegoro SR. Acyclovir therapy in children with varicella without complications. Sari Pediatr 2010;11:440-47.

24. Widyaswari R, Wiedyaningsih C. Evaluation of Prescription Drug Profile and Availability of Drug Formulas for Children at Province Public Health Care Center Yogyakarta, Dissertation. Yogyakarta: Universitas Gadjah Mada; 2012.

25. Wiedyaningsih $\mathrm{C}$. The Driving Factor for Prescribing Concoctions for Outpatient Pediatric Patients, Dissertation. Yogyakarta: Universitas Gadjah Mada; 2013.

26. Setyaningrum N, Khamsani H, Mulywati R. The use of off-label drugs in outpatient pediatric patients in Pratama Swasta Clinic at Sleman Yogyakarta. J Sains Farm Klinis 2019;6:37-45.

27. Abdulkadir W. Evaluate the rational use of antibiotics in Gorontalo Hospital with the gyssens category method. J Sainstek 2015;8:11-8.

28. Sauriasari R, Aulia AA, Swastika A. Evaluation of the suitability of prescription writing in non-pneumonia ARI cases at MTBS public health care center, Cengkareng Jakarta. Pharm Sci Res 2017;4:81-7.

29. Oktaviana E, Hidayati IR, Pristianty L. The influence of knowledge on rational use of paracetamol in self-medication (study on housewives at Sumberpoh village, Maron Kabupaten Probolinggo. J Farm Ilmu Kefarmasian Indones 2017:4:44.

30. Pandiangan CP, Carolia N, Suwandi JF, Tarigan A. The relationship of drug related problems (DRPs) in the category of anti-hypertensive drug dosage with blood pressure at RSUD Jendral Ahmad Yani Metro 2014. Artikel Penelitian 2017;4:293-300.

31. Cahyani IW. Identification of Drug Related Problems (DRPs) in the Category of Overdoses and Subdoses in Prescribing Anti-tuberculosis (OAT) Adult Patients, Dissertation. Surakarta: Faculty of Mathematics and Sciences Universitas Sebelas Maret; 2014.

32. Sun XJ, Li ZH, Zhang Y, Zhou G, Zhang JQ, Deng JM, et al. Combination of erythromycin and dexamethasone improves corticosteroid sensitivity induced by CSE through inhibiting PI3K- $\delta /$ Akt pathway and increasing GR expression. Am J Physiol Lung Cell Mol Physiol 2015;309:L139-46.

33. Puspitasari AW, Azizahwati A, Hidayat AR. Analysis of potential drugs interaction on antihypertension drugs prescription in community health center of Sukmajaya district in period of June-November 2015. Asian J Pharm Clin Res 2017;10:61-5. 